\title{
Rodents of the North Urals in the Late Pleistocene and Holocene
}

\author{
Anastasia Teterina \\ Institute of Plant and Animal Ecology, Russian Academy of Sciences, 2028 Marta Street, 620144 Ekaterinburg, Russia
}

\begin{abstract}
A B S T R A C T
Data on fossil micromammals known at present from the North Urals sites allow us to trace the history of rodent communities beginning from the Middle Weichselian up to the present and to reveal some temporal and spatial patterns in their changes. Five fauna types were distinguished among the fossil local faunas known at present. Throughout the Late Pleistocene only tundra-steppe faunas existed in the North Urals, which differed in time and space mainly by relative abundances of three dominant species Dicrostonyx gulielmi, Microtus gregalis and Lemmus sibiricus, and in some cases by species diversity. Early and Middle Holocene faunas reflect a transition from communities characteristic of tundra-steppe to forest and, in particular, taiga environments. Late Holocene faunas have a typical taiga character. Tendencies of temporal dynamics of faunas correlate with those revealed for other parts of the Urals. Differences between faunas of the different slopes (western and eastern) of the North Urals can be explained by the same factors which determine the different climate conditions there at present.
\end{abstract}

(c) 2008 Elsevier Ltd and INQUA.

\section{Introduction}

The North Urals is part of the Urals mountain range situated between $59^{\circ} \mathrm{N}$ and $63^{\circ} \mathrm{N}$. The climatic regime of the territory differs east and west of the watershed due to the barrier role of the mountain range which blocks Atlantic moist air masses from moving to the east, so the humidity in the Pre-Urals and mountain part of the territory is higher than on the eastern slopes and in the foothills of the TransUrals. The North Urals falls almost completely within the northern taiga subzone and only in the southern part includes a Middle taiga area. Altitudinal vegetation belts are pronounced at the highest mountain peaks (Urals and Pre-Urals, 1968).

In this paper, only rodents and lagomorphs (pikas) are considered, because the identification of insectivore fossil remains constitutes a separate and complicated problem.

\section{Rodent faunas of the North Urals}

The North Urals rodent fauna at present consists of forest species typical of the taiga zone: Clethrionomys glareolus, Clethrionomys rufocanus, Clethrionomys rutilus, Micromys minutus, Microtus agrestis, Myopus schisticolor, Pteromys volans, Sciurus vulgaris, Sicista betulina, and Tamias sibiricus, and intrazonal species preferring riverine habitats: Arvicola terrestris and Microtus oeconomus. Besides, there are two synanthropic species Rattus norvegicus and Mus musculus, and one introduced species Ondatra

E-mail address: nsmirnov@ipae.uran.ru zibethicus. Distribution area borders of several species lay in the region: Apodemus uralensis, Apodemus agrarius, and Microtus arvalis are present in the southern part (up to $60^{\circ} \mathrm{N}$ ), and the southern edges of Microtus middendorffii and Ochotona hyperborea areas reach the northern part of the North Urals. Dominant species in the rodent communities are voles of the genus Clethrionomys (Gromov and Erbajeva, 1995; Berdyugin, 1999; Bolshakov et al., 2000).

The work presented in this paper is based on the analysis of 21 rodent local faunas of different ages from 10 cave excavation sites (Fig. 1) (Smirnov, 1996; Smirnov et al., 1999; Teterina, 2002; Teterina and Ulitko, 2002). All sites known at present are situated in the southern part of the territory (the southernmost at $59^{\circ} \mathrm{N}$, the northernmost at $62^{\circ} \mathrm{N}$ ). Faunas were dated by ${ }^{14} \mathrm{C}$ or dates are based on the archaeological data, and in some cases the morphology of species (mostly Dicrostonyx sp.) and correlations with other, dated faunas from nearby territories were used for this purpose. Some of the sites are multilayered and contain material of different ages, allowing us to trace temporal changes in communities. The most informative for the purpose of a reconstruction of the temporal dynamics of rodent communities is Cheremuhovo 1, containing a sequence of layers with bone material of different ages beginning from 28 ka up to the present (Fig. 2).

Existing materials allow us to characterize rodent faunas beginning from the Middle Weichselian (the oldest faunas were beyond the ${ }^{14} \mathrm{C}$ method and their age was assessed on the basis of Dicrostonyx morphology) up to the present.

For a description and analysis of the faunas, the species were divided into four zonal-biotopic groups according to their environmental preferences:

1040-6182/\$ - see front matter (c) 2008 Elsevier Ltd and INQUA. doi:10.1016/j.quaint.2008.05.018 


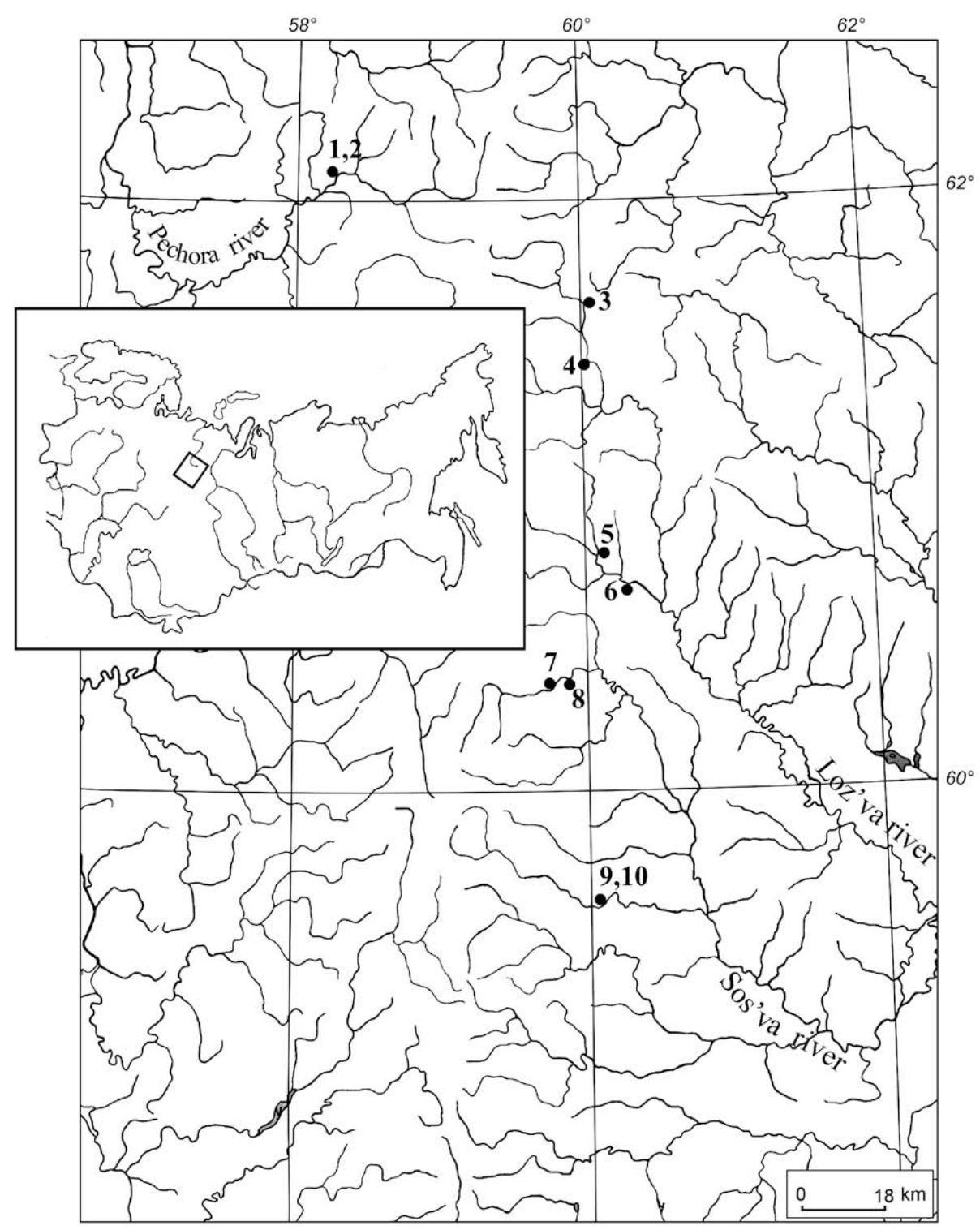

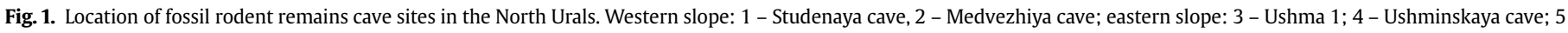
- Toltiyskaya cave; 6 - Shaitanskaya cave; 7 - Lis'ya cave; 8 - Cheremuhovo 1; 9 - Zhilische Sokola; 10 - Kakva 4.

- tundra (collared lemming, Siberian lemming, Middendorff's vole), - steppe (narrow-skulled vole, steppe lemming, yellow steppe lemming, gray hamster, ground squirrel, steppe pika),

- forest (common red-backed vole, gray large-toothed redbacked vole, northern red-backed vole, field vole, wood lemming, northern birch mouse, harvest mouse, wood mouse, squirrel, Siberian chipmunk, flying squirrel),

- intrazonal riverine (root vole, water vole).

Cluster analysis performed on data on relative abundances of different species remains in local faunas allowed us to distinguish five types of fauna and within two of these also subtypes. They principally differ by dominant species and their relative abundances, and consequently replaced each other in time and space. Most of the fauna types are represented by different chronological and local variations.

\subsection{Late Pleistocene}

All faunas include remains of three species: Dicrostonyx gulielmi, Lemmus sibiricus and Microtus gregalis, and the share of their summarized relative abundances constitutes not less than $70 \%$ of the total number of remains. Differences between faunas are determined by the different proportions in the abundances of these species remains. Low species diversity and a high degree of noncorrespondence are the characteristics for faunas of this period (Table 1).

\subsection{Middle Weichselian}

\subsubsection{Fauna type 1}

Dicrostonyx sp. dominates. Subtype 1a $M$. gregalis is subdominant. The subtype is represented by the local fauna from pit section 2 of Zhilische Sokola on the eastern slope. The other known faunas of this subtype are dated to a later period, the Last Glacial Maximum and the deglaciation. Compared to these, the fauna of Zhilische Sokola differs: no sharply pronounced D. gulielmi dominance; significant species diversity due to the number of forest and steppe species; a comparatively high share of steppe species remains. Species preferring xerophylic habitats (D. gulielmi, M. gregalis and steppe species) constitute the bulk of the remains; the 


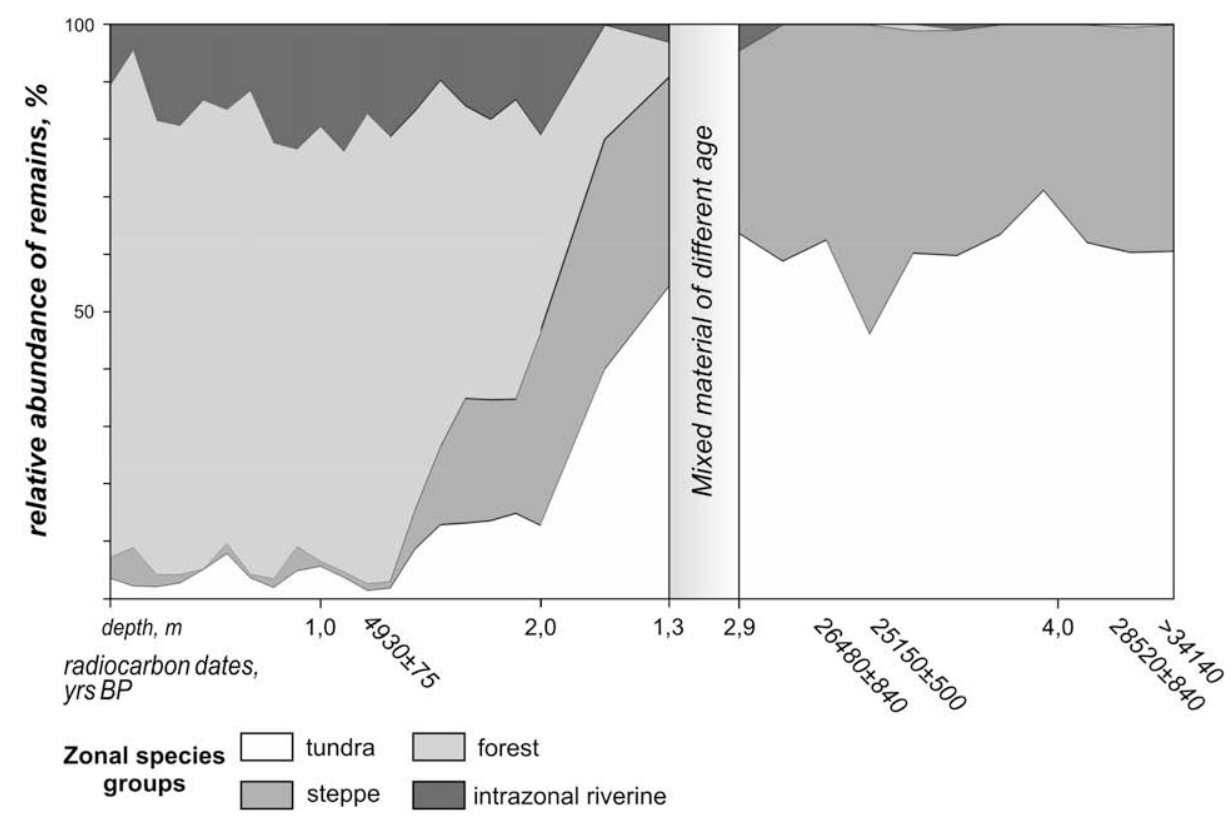

Fig. 2. Changes in the relative abundances of remains in the zonal species groups in the sequence of Cheremuhovo 1.

proportions of remains of tundra and steppe species are very similar.

Subtype 1b L. sibiricus is subdominant. The fauna is described from pit section 1 of Zhilische Sokola. No similar faunas are known in the Urals. The Dicrostonyx dominance is poorly expressed; the total proportion of tundra species remains is the highest and that of the steppe species, accordingly, the lowest among all local faunas known from the eastern slope. Species preferring wet habitats ( $L$. sibiricus, $M$. middendorffi, $M$. oeconomus, and A. terrestris) constitute considerable numbers of remains. The relative abundance of Middendorff's vole is much higher here than in any other local fauna of the North Urals. The presence of remains of such typical steppe species as steppe lemming gives the fauna a pronounced disharmonious appearance.

\subsubsection{Fauna type 2}

L. sibiricus dominates. Such faunas were found only in the lower layers of the Studenaya cave on the western slope of the North Urals. The degree of $L$. sibiricus dominance changes with depth (from 76 in the lower to 46 in the upper part), D. gulielmi is the second in abundance, followed by $M$. gregalis.

Compared to other Late Pleistocene faunas, all faunas of the Middle Weichselian are characterized by a considerable proportion of remains of species preferring wet areas of the modern tundra, first of all $L$. sibiricus and on the eastern slope also $M$. middendorffii. $M$. oeconomus and $A$. terrestris are always present in these faunas, while in faunas of the succeeding Last Glacial Maximum and deglaciation periods they are absent or extremely rare $(M$. oeconomus). The share of the total number of remains of the three dominant species (70-79\%) in the faunas of the eastern slope is the lowest over the whole Late Pleistocene period in the North Urals. As only four local faunas of this time are known and they have no accurate dates, it is impossible to describe the patterns of temporal dynamics of the faunas throughout this period.

\subsection{Bryansk interstadial (Denekamp), Last Glacial Maximum and deglaciation}

Three local faunas of this time are known from the eastern slope and two from the western. Beginning from the Bryansk interstadial and nearly up to the beginning of the Late Glacial interstadial, all known faunas are of type $\mathbf{1}$ and subtype 1a, in which $D$. gulielmi dominates and $M$. gregalis is subdominant. All faunas have a very similar appearance. The dominance of $D$. gulielmi is pronounced (in the different faunas of the eastern slope $40-50 \%$, of the western $74-$ $87 \%$ ). The share of $L$. sibiricus remains is not more than $15 \%$. The species diversity is low. Other species present in the faunas beside the dominants are Clethrionomys voles, M. oeconomus, M. middendorffi, Ochotona pusilla and on the eastern slope also Lagurus lagurus; the total share of these species remains is extremely low (not more than 10\%). On the western slope, the relative abundance of $D$. gulielmi remains is much higher and the species diversity is lower than on the eastern slope; to some extent this can be explained by the more northern location of the sites.

Two faunas (layer 9 in the Shaitanskaya cave and the lower part of layer 8 in Cheremuhovo 1) are younger than the others and very similar in species composition and structure. They are distinguished by a lower total share of tundra species remains (55-56\%, while in the other faunas this is $60 \%$ and more) and a higher total share of forest and intrazonal species remains ( $9 \%$ in Cheremuhovo 1 and $4 \%$ in Shaitanskaya, while in the other faunas this is not more than $2 \%)$.

\subsection{Late Glacial interstadial}

For this period one ${ }^{14} \mathrm{C}$ dated local fauna is known from the western slope and two from the eastern, dated by the position in the sequence in relation to ${ }^{14} \mathrm{C}$ dates and archaeological data. One other fauna, from Kakva 4, is very close to this period $\left({ }^{14} \mathrm{C}\right.$ date $12800 \pm 300 \mathrm{ka} \mathrm{BP}$ ) and analogous to the faunas of this period by species composition and structure. All faunas are of type 3 , in which M. gregalis dominates (the relative abundance of remains is $32-42 \%$ ). On the western slope, $L$. sibiricus is the first subdominant (26-30\%) and $D$. gulielmi is the third in relative abundance - subtype 3a.

On the eastern slope, the first subdominant is D. gulielmi (24$36 \%$ ) and $L$. sibiricus is in third place - subtype $3 \mathbf{b}$. The total share of the other species remains is $17-20 \%$, in Kakva $4-10 \%$; on the western slope these are $M$. oeconomus, $M$. agrestis, and A. terrestris, voles of the genus Clethrionomys, M. schisticolor and O. pusilla, and on the eastern slope also L lagurus and Cricetulus migratorius. 


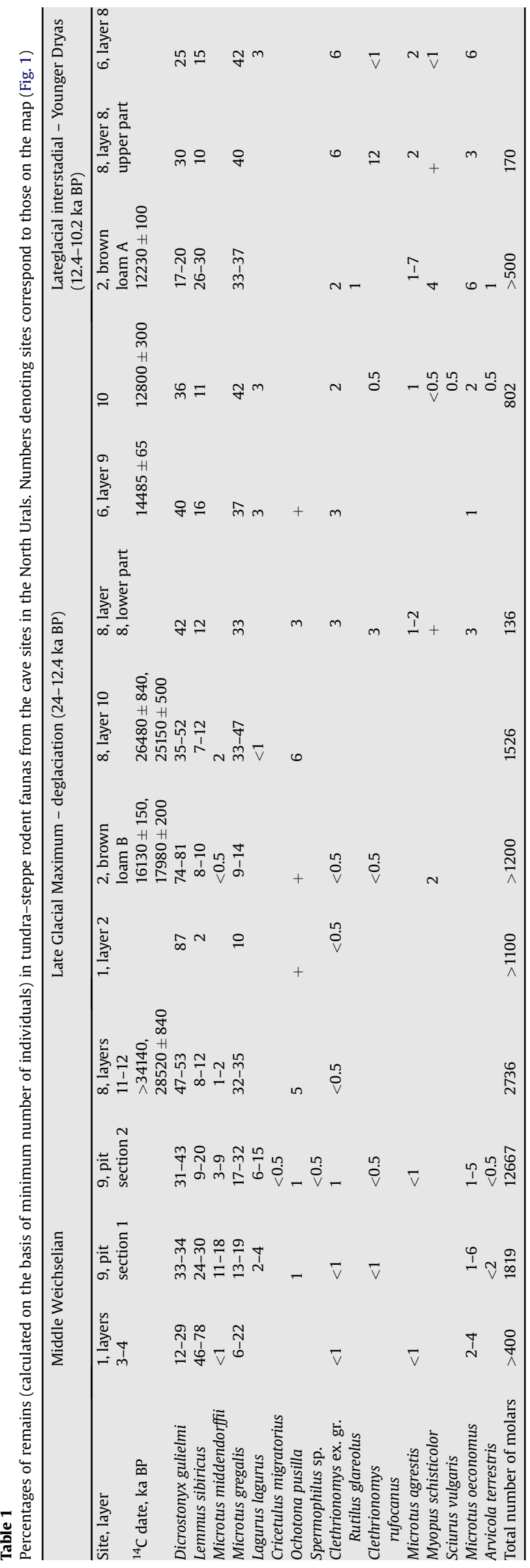

The species diversity of faunas is higher than that of the preceding period, mostly due to the presence of more riverine and forest species, but the general appearance of the faunas stays the same, as the bulk of the remains belongs to the three dominant open habitat species.

\subsection{Preboreal - Boreal}

There are no reliable data on faunas of this period. Supposedly it can be characterized by materials from layer 7 of the Shaitanskaya cave and the upper layers of the Medvezhiya cave. There are no ${ }^{14} \mathrm{C}$ dates in both cases; the material is dated on the basis of the location in the sequence in relation to ${ }^{14} \mathrm{C}$ dates and archaeological artefacts. Probably, the lower horizons of layer 7 in Cheremuhovo 1 also belong to this period. In the Shaitanskaya cave the most abundant are remains of the three species which dominated the Late Pleistocene faunas, their total share is $72 \%$; an insignificant number of remains constitute those of two typical steppe species (1.7\% total), and the rest (24\%) is made up by forest and riverine species. To give an accurate characteristic of the fauna structure of the Medvezhiya cave is difficult because of the limited quantity of bone material there. A considerable number of remains belong to the same three species (total share $41-46 \%$ ). At the same time the proportion of remains of voles of the genus Clethrionomys is also high (34-29\% total), and the remains of the other species constitute not less than $5 \%$. The presence of $S$. vulgaris remains should also be noted.

There are no data on the Holocene rodent fauna history from the western slope with the exception of the two layers of the Medvezhiya cave described above. So in the characterization of the later period only faunas of the eastern slope were considered (Table 2).

\subsection{Atlantic}

\subsubsection{Fauna type 4}

Faunas of transitional appearance were found in layer 7 of Cheremuhovo 1 (dated by archaeological data), Lis'ya cave $\left({ }^{14} \mathrm{C}\right.$ dated), Toltiyskaya cave, and layer 3 of Ushminskaya cave (dated on the basis of the location in a sequence in relation to archaeological data). The faunas reflect the change of the composition of the community from tundra-steppe to modern taiga. Each biotopic group of species in these faunas is represented by significant numbers of remains and each of such groups includes species with a relative abundance of not less than $10 \%$; in comparison with preceding and succeeding periods faunas have a higher 'equitability index' (not less than 0.87). Remains of forest and riverine species constitute half or more of the total number of remains. The forest species diversity is the highest of the North Urals for the whole period considered. At the same time all the species characteristics of the Late Pleistocene continue in the fauna composition. The existence of such a fauna type, in which species with different biotopic preferences constitute a significant part of the remains, is a result of the mountain environment in which differently oriented slopes provide conditions suitable for different vegetation types, and thus the mosaic of biotopes forms in which animals sharply different in their ecological demands can exist.

\subsection{Subboreal - present}

All faunas of this period belong to the type 5 - taiga faunas. They reflect the composition and structure of rodent communities close to those of the modern taiga. The bulk of the remains belongs to forest and riverine species, while the total share of tundra and steppe species remains constitutes not more than $5 \%$. Unlike the modern fauna, they include several species not inhabiting the North Urals at present: Dicrostonyx cf. torquatus, M. gregalis, $L$. sibiricus, M. middendorffii and $O$. pusilla. The last two species were 
Table 2

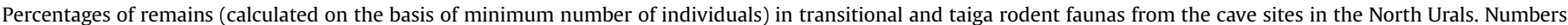
denoting sites correspond to those on the map (Fig. 1)

\begin{tabular}{|c|c|c|c|c|c|c|c|c|c|}
\hline & Preboreal - Bor & & & Atlantic & & & & Subboreal - p & resent \\
\hline $\begin{array}{l}\text { Site, layer } \\
{ }^{14} \mathrm{C} \text { date, ka BP }\end{array}$ & 2, upper layers & 6 , layer 7 & 8 , layer 7 & $\begin{array}{l}7 \\
5037 \pm 173 \text { (upper part) } \\
7213 \pm 60 \text { (lower part) }\end{array}$ & 5 & 4 , layer 3 & $\begin{array}{l}\text {, layers 2,3,6 } \\
4930 \pm 75 \\
\text { (lower part) }\end{array}$ & 4 , layers $1-2$ & 3, upper layers \\
\hline Dicrostonyx ex. gr. gulielmi-torquatus & $8-9$ & 24 & $9-15$ & $<0.5$ & 10 & 20 & $1-5$ & 7 & 1 \\
\hline Lemmus sibiricus & $17-20$ & 16 & + & 9 & & & $<1$ & & \\
\hline Microtus middendorffii & & & $<1$ & & & & $<0.5$ & & \\
\hline Microtus gregalis & $13-21$ & 32 & $7-32$ & 21 & 8 & 6 & $1-4$ & & \\
\hline Lagurus lagurus & & 1 & $<1$ & & $<1$ & & & & \\
\hline Cricetulus migratorius & & $<0.5$ & $<0.5$ & & & & & & \\
\hline Ochotona pusilla & + & & $<1$ & $<1$ & & & $<0.5$ & & \\
\hline Spermophilus sp. & & & & $<0.5$ & & & & & \\
\hline Clethrionomys ex. gr. rutilus glareolus & 17 & 8 & $13-21$ & 20 & 6 & 22 & $16-29$ & 37 & 7 \\
\hline Clethrionomys rufocanus & $12-17$ & 4 & $12-26$ & 17 & 14 & 24 & $19-25$ & 22 & 9 \\
\hline Microtus agrestis & $8-10$ & & $8-16$ & 5 & 13 & 11 & $18-27$ & 6 & 9 \\
\hline Myopus schisticolor & 5 & 2 & $4-8$ & 3 & 8 & 13 & $5-12$ & 24 & 4 \\
\hline Sciurus vulgaris & $<1$ & & $<1$ & 2 & 9 & 2 & $<0.5$ & & 10 \\
\hline Tamias sibiricus & & & & $<0.5$ & & & & & $<1$ \\
\hline Pteromys volans & & & & & & & & & $<1$ \\
\hline Sicista betulina & & & $<1$ & $<1$ & & & 1 & & $<0.5$ \\
\hline Apodemus uralensis & & & $<0.5$ & & & & & & \\
\hline Micromys minutus & & & $<1$ & & & & & & \\
\hline Microtus oeconomus & $7-13$ & 12 & $10-18$ & 13 & 14 & & $11-21$ & 4 & 21 \\
\hline Arvicola terrestris & 8 & & $<1$ & 7 & 19 & 2 & $<1$ & & 37 \\
\hline Total number of molars & $>250$ & & 4042 & 1778 & 435 & & 9550 & & 1721 \\
\hline
\end{tabular}

found only in the lower part of layer 6 in Cheremuhovo 1 dated to $4930 \pm 75 \mathrm{ka}$ BP. It is impossible to state for certain if all these species remains are an admixture of an earlier age or not, but the constant presence of Dicrostonyx cf. torquatus and $M$. gregalis in all Late Holocene faunas is a testimony that these two species disappeared from the North Urals relatively recently. Taiga faunas are represented in two variants. In the first, the greatest part of the remains belongs to forest species, they constitute not less than $55 \%$ (upper layers of Cheremuhovo 1 and layers 1-2 of Ushminskaya cave). In the second case, the remains of riverine species constitute more than half of the total number of remains: the upper layers of Ushma 1 shelter, where the most abundant species are $A$. terrestris (37\%), and M. oeconomus (21\%).

\section{Discussion and conclusions}

The species lists and structures of fossil local faunas in the North Urals change according to their latitudinal characteristics and location on the western or eastern slopes. In faunas of the western slope, among the remains of open habitat species, the proportion of those preferring wet conditions (primarily L. sibiricus and M. middendorffii) compared to those preferring dry conditions (D. gulielmi, steppe species) is higher than the same index in faunas from the eastern slope, with the exception of the Last Glacial Maximum when the values were similar for both slopes. In more northern faunas (Ushma 1 and the Studenaya, Medvezhiya and Ushminskaya caves), the total relative abundance of tundra species remains always exceeds that of steppe species. In the other, more southern faunas, the same ratio is recorded for the Late Pleistocene period, but in the Late Glacial interstadial it changes to more steppe than tundra and does not alter throughout the Early and Middle Holocene.

The main patterns of rodent fauna changes through time can be summarized as follows. Tundra-steppe faunas exist in the North Urals throughout the Late Pleistocene, but their appearance changes in different periods and places. During the Middle Weichselian, the species diversity of the faunas is pretty high and the number of species preferring humid habitats is significant. Later, during the Bryansk interstadial, the Late Glacial Maximum and almost the whole period of deglaciation, faunas are characterized by low species diversity, very low equitability indexes (0.33-0.76) and uniform composition and structure over the whole territory: D. gulielmi dominates strongly, the share of $M$. gregalis remains is large, and the remains of $L$. sibiricus are also numerous in the faunas; the remains of other species are very scarce. At the end of the deglaciation and throughout the Late Glacial interstadial the character of the faunas continues to be tundra-steppe but the role of forest and intrazonal species becomes more significant. The dominant species change, $M$. gregalis becomes the principal dominant species everywhere and subdominants are $L$. sibiricus on the western and D. gulielmi on the eastern slopes. In the Holocene, the relative abundances of forest and intrazonal species gradually increase, while those of the three principal species of tundrasteppe faunas in the region (D. gulielmi, M. gregalis, $L$. sibiricus) decrease. Faunas were of transitional character from tundra-steppe to taiga beginning at least from $7000 \mathrm{ka} \mathrm{BP}$ and up to $5000 \mathrm{ka}$ BP. Consequently, the species diversity during this time was higher than at present. About 5000 years ago communities of typical taiga appearance already existed in the North Urals, but such faunas included more species than the present ones. At the same time faunas of transitional character could persist in other areas (the taiga fauna from Cheremuhovo 1 and the transitional fauna from Lis'ya have very close ${ }^{14} \mathrm{C}$ dates).

Temporal patterns of fauna composition and structure dynamics correlate with those revealed for the other regions of the Urals (corrected for latitudinal differences) (Smirnov, 1994). The spatial differences in fauna composition and structure first and foremost are manifested in the ratios of remains of open habitat species (tundra and steppe). The differences of structure and composition of faunas from different slopes in the Late Pleistocene can be explained by the same factors that determine the differences in climate and landscape conditions of the western and eastern slopes at present, which is primarily a difference in the precipitation regime.

\section{Acknowledgements}

The author is very grateful to those who participated in excavations in the North Urals in 1997-2000. I would like to thank my colleagues N.G. Smirnov, P.A. Kosintsev, O.P. Bachura and T.V. Fadeeva for valuable 
discussions of the issues raised in this paper. The work is supported by RFBR grant 02-04-49181 and the "Biodiversity" programme, GK BD N 14.

\section{References}

Berdyugin, K.I., 1999. Rodent communities of the Northern Urals. Russian Journal of Ecology 30 (2), 119-125.

Bolshakov, V.N., Berdugin, K.I., Vasil'eva, I.A., Kuznetsova, I.A., 2000. Mammals of the Sverdlovskiy Region, Handbook. Ekaterinburg, Ekaterinburg, pp. 1-240 (in Russian).

Gromov, I.M., Erbajeva, M.A., 1995. The mammals of Russia and adjacent territories. Lagomorphs and rodents. issue 167. Handbooks of Fauna of Russia. Zoological Institute of RAS, St. Petersburg, pp. 1-522 (in Russian)

Smirnov, N.G., 1994. Rodents of the Urals and adjacent territories in the Late Pleistocene and Holocene. Thesis for the Degree of Doctor of Science in Zoology, Ekaterinburg, pp. 1-58 (in Russian).
Smirnov, N.G., 1996. Diversity of small mammals in the North Urals during the Late Pleistocene and Holocene. In: Smirnov, N.G., Bykova, G.V. (Eds.), Materials and Research on the History of the Modern Fauna of the Urals. Ekaterinburg, Ekaterinburg, pp. 39-83 (in Russian).

Smirnov, N.G., Kuz'mina, E.A., Kourova, T.P., 1999. New data on rodents of the Late Glacial in the North Urals. In: Smirnov, N.G., Golovachev, I.B. (Eds.), Biota of the Pre-Urals Subarctic in Late Pleistocene and Holocene. Ekaterinburg, Ekaterinburg, pp. 68-77 (in Russian).

Teterina, A.A., 2002. Fossil micromammal faunas from the North Urals. In: Kosintsev, P.A. (Ed.), Urals Fauna in the Pleistocene and Holocene. Scientific Papers. Universitet Ekaterinburg, pp. 111-135 (in Russian).

Teterina, A.A., Ulitko, A.I., 2002. The new localities of the Late Pleistocene and Holocene mammal faunas in the North Urals. In: Kosintsev, P.A. (Ed.), Urals Fauna in the Pleistocene and Holocene. Scientific Papers. Universitet Ekaterinburg, pp. 155-161 (in Russian).

Urals and Pre-Urals, 1968. USSR Environments and Natural Resources. Nauka, Moscow, pp. 1-461 (in Russian). 